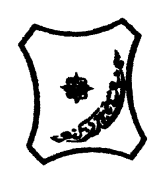

Bayero Journal of Pure and Applied Sciences, 10(1): 178 - 182

Received: January, 2017

Accepted: May, 2017

ISSN $2006-6996$

\title{
PREPARATION AND CHARACTERIZATION OF SOAPS MADE FROM SOYA BEAN OIL AND NEEM OIL BLENDS
}

\author{
* Mohammed Abdullahi Baba ${ }^{1}$, Simeon Sunday Jakada ${ }^{1}$ and Aminu Sabo Musa ${ }^{2}$ \\ ${ }^{1}$ Department of Polymer and Textile Science, Ahmadu Bello University, Zaria, Nigeria \\ ${ }^{2}$ Department of Textile Technology, Kano State Polytechnic, Kano \\ mohammedbaba700@gmail.com; simeonjaks@yahoo.com \\ aminusabosm@gmail.com
}

\begin{abstract}
This research work deals with the preparation of soaps from neem oil and soya bean oil blends and analyses the soap produced. The soaps were produced using cold process technique by varying the percentage of oils; (soya bean oil and neem oil) in the ratio of 100\%, 90/10\%, 80/20\%, 70/30\%, $60 / 40 \%, 50 / 50 \%, 40 / 60 \%, 30 / 70 \%, 20,80 \%, 90 / 10 \%$ and $100 \%$ to obtain soap samples $A, B, C$, $D, E, F, G, H, I, J$ and $K$, respectively. The oils and a calculated amount of base at $33^{\circ} \mathrm{C}-43^{\circ} \mathrm{C}$ was mixed to form soap and allowed to cure. The properties of the soap such as; pH values, total alkali, $\%$ fatty matter, moisture content and form height were analysed, and the values range from $7.9-$ 9.0, $0.12-0.37 \mathrm{~g}, 60-80 \%, 13-18.6$ and $12.0-15.6 \mathrm{~cm}$ were obtained, respectively. Sensitivity test was conducted for soap sample I (70\% neem oil and $30 \%$ soya bean oil) using isolated bacteria; Escherichia coli, staphylococcus aureus and salmonella typhi against the control sample at varying concentrations. Generally, the performance of the soaps produced was found to be good. Keywords: Neem oil, Soya bean oil, pH value, Sensitivity, Oil blends
\end{abstract}

\section{INTRODUCTION}

Soap is a chemical compound or mixture of chemical compounds resulting from the fatty acids or fatty glycerides with a metal radical. Soaps are mainly used as surfactants for washing, bathing, and cleaning purpose (Kuntom et al., 1996). Neem oil used in soap production is obtained from seeds of the neem tree and is greenish-yellow in colour. It is used to blend other oils together in soap production. Soybean oil is a vegetable oil extracted from the seeds of the soybean plant (Glycine max), and often has a dark yellow or faint green colour. It is one of the most widely consumed cooking oils, and as a base for printing inks and oil paints (Jackson et al., 2004).The production of soap of high quality from blends of neem oil and soya bean oil is the basis for this work, also to investigate the properties of the soap produced.

\section{MATERIALS AND METHODS}

Preparation of oils blend: The blends of oil comprises of Soya bean oil and neem oil. The ratio was varied to obtain the different blends.

Table 1: Preparation of oil blends

\begin{tabular}{lccccccccccc}
\hline \multicolumn{10}{c}{ Proportion of oil blends } \\
\hline Oils & $\mathrm{A}$ & $\mathrm{B}(\%)$ & $\mathrm{C}(\%)$ & $\mathrm{D}(\%)$ & $\mathrm{E}(\%)$ & $\begin{array}{l}\mathrm{F} \\
(\%)\end{array}$ & $\mathrm{G}(\%)$ & $\mathrm{H}(\%)$ & $\mathrm{I}(\%)$ & $\mathrm{J}(\%)$ & $\mathrm{K}(\%)$ \\
Neem & 100 & - & 10 & 20 & 30 & 40 & 50 & 60 & 70 & 80 & 90 \\
Soya bean & - & 100 & 90 & 80 & 70 & 60 & 50 & 40 & 30 & 20 & 10 \\
Total & 100 & 100 & 100 & 100 & 100 & 100 & 100 & 100 & 100 & 100 & 100 \\
\hline
\end{tabular}

Preparation of lye:

Using the saponification values of the oils and their weight in gram, the required quantity of caustic soda was obtained using the relation:

(Amount of fat) $\times$ (Saponification value of the fat) = (Amount of lye) (Olatunja, 2013).

\section{Soap Preparation}

$100 \mathrm{~g}$ of the oil blend $(\mathrm{A})$ was measured and poured into a $250 \mathrm{~mL}$ beaker; it was heated in order to quicken the reaction between the alkali and the fat. $A$ calculated amount of $\mathrm{NaOH}$ was weighed and added to a fixed amount of distilled water to prepare a $0.2 \mathrm{~N}$ $\mathrm{NaOH}$ solution. At a temperature of $33-43^{\circ} \mathrm{C}$, the aqueous base solution was slowly added into the oils while stirring continuously until the mixture began to thicken. Finally the mixture was poured into a plastic mold and allowed to cure. The same procedure was repeated for Samples B, C, D, E, F, G, H, I, J and K to obtain the various blends. 
Table 2: Weight of caustic soda and volume of water used to prepare the caustic soda solution for each sample.

\begin{tabular}{cccc}
\hline Samples & $\begin{array}{c}\text { Sodium hydroxide } \\
(\mathrm{NaOH})(\mathrm{g})\end{array}$ & $\begin{array}{c}\text { Potassium hydroxide } \\
(\mathrm{KOH})(\mathrm{g})\end{array}$ & Distilled water $(\mathrm{mL})$ \\
\hline A & 12.92 & 18.43 & 35 \\
B & 12.73 & 17.86 & 35 \\
C & 12.95 & 17.92 & 35 \\
D & 12.77 & 17.97 & 35 \\
E & 12.79 & 18.03 & 35 \\
F & 12.81 & 18.09 & 35 \\
G & 12.83 & 18.15 & 35 \\
H & 12.84 & 18.20 & 35 \\
I & 12.86 & 18.26 & 35 \\
J & 12.88 & 18.32 & 35 \\
K & 12.90 & 18.37 & 35 \\
\hline
\end{tabular}

\section{Characterization of the Soap Produced Foamability Test}

About $2.0 \mathrm{~g}$ of each of the soap sample was dissolved and added into $250 \mathrm{~mL}$ measuring cylinder containing $100 \mathrm{~mL}$ of distilled water. The mixture was shaken vigorously for about 5 minutes so as to generate foams. The measuring cylinder was allowed to stand for about $10 \mathrm{~min}$. The height of the foam in the solution was then measured and recorded(Taiwo et al, 2008). The same procedure was repeated for commercial soap in comparison with the produced soaps.

\section{Determination of Insoluble Matter in Water [ASTMD460-91(2014)]}

$1 \mathrm{~g}$ of each soap sample was dissolved in $10 \mathrm{~mL}$ hot distilled water and transferred into a filter paper of known weight. The filter paper and the residue was dried and weighed. The difference in weight representing the matter insoluble in water was obtained as follows:

Matter insoluble in water $=W_{2}-W_{1}$

\section{Determination of Moisture Content [ASTMD455- 69 (2006)]}

$2 \mathrm{~g}$ of the sample soap was measured and placed on an empty glass dish of known weight and transferred into air circulation oven at $105^{\circ} \mathrm{C}$, for 2 hours. The dish was re-weighed and the result were obtained and discussed. The percentage moisture content was calculated for the soap samples using the expression below:

Percentage moisture content $=\left(\mathrm{W}_{1}-\mathrm{W}_{2}\right) /\left(\mathrm{W}_{1}-\mathrm{W}_{0}\right)$ $\times 100 \%$.

Where, $W_{1}=$ weight of sample and empty dish, $W_{2}=$ weight of dried sample and dish after heating, and $\mathrm{W}_{0}$ $=$ weight of empty dish.

\section{Determination of PH}

$5 \mathrm{~g}$ each of the soaps blend was weighed and dissolved in $10 \mathrm{~mL}$ distilled water in a beaker. The $\mathrm{PH}$ meter was dipped into the solution and the $\mathrm{pH}$ reading was recorded(Umar $M, 2002)$. The same procedure was repeated for the control sample.

\section{Determination of Total Alkali}

$10 \mathrm{~mL}$ of neutralized alcohol was added to $5 \mathrm{~g}$ of each soap sample with $2.5 \mathrm{~mL}$ of $1 \mathrm{M} \mathrm{H}_{2} \mathrm{SO}_{4}$ solution and heated until the soap sample was completely dissolved. The solution was titrated against $1 \mathrm{M} \mathrm{NaOH}$ using phenolpthalein as indicator.

The total alkali was calculated using the relation:

\%Total alkali $=\left(\mathrm{V}_{\mathrm{A}}-\mathrm{V}_{\mathrm{B}}\right) / \mathrm{W} \times 100 \%$

Where: $\mathrm{V}_{\mathrm{A}}=$ volume of acid used $\left(\mathrm{cm}^{3}\right), \mathrm{V}_{\mathrm{B}}=$ volume of base $\left(\mathrm{cm}^{3}\right), \mathrm{W}=$ weight of soap (g) (Taiwo, 2008).

\section{Determination of Total Fatty Matter (tfm)} (ADAC, 1998)

About $5 \mathrm{~g}$ of each soap sample was dissolved in $50 \mathrm{~mL}$ of distilled water and heated. $10 \mathrm{~mL}$ of $\mathrm{H}_{2} \mathrm{SO}_{4}$ was added to the solution while heating until a clear solution was obtained. $2 \mathrm{~g}$ of wax was added and reheated until the fatty acid present in the solution was solidified. The solution was allowed to cool to form a cake; the cake was removed and allowed to dry and weighed and the result was obtained using the following expression:

$\% \mathrm{TFM}=(\mathrm{A}-\mathrm{Z}) / \mathrm{W} \times 100 \%$

Where, $\mathrm{A}=$ weight of the obtained cake, $\mathrm{Z}=$ weight of the wax, and $W=$ weight of the soap.(Ara, I. 2010).

\section{Determination of Hardness}

To each sample of the soap, a needle to which a lead fishing weight is attached was lowered into the surface of the soap. The distance at which the needle enters into the soap was measured and recorded both for the produced blend of soap and the controls sample soap.

\section{Antimicrobial Test for the Soap Produced}

The antimicrobial test of the produced neem and soya beans soap was conducted at the microbiology laboratory of the Department of Pharmaceutical Sciences, Ahmadu Bello University, Zaria. This was carried out using the test specimen organisms from the laboratory which are;
i. Escherichia coli
ii. Staphylococcus aureus
iii. Salmonella typhi 


\section{Standardization of the Culture Media}

The standardization of the culture media which is in liquid form includes: Muller Hilton Agar (MHA), Nutrient Agar (NA), and the Muller Hinton Broth (MHB). These were used also in the determination of the Minimum Inhibitory Concentration (MIC) and the minimum bactericidal concentration (MBC).

\section{Sensitivity Test}

The isolated bacterial were standardized and prepared into a Muller Hinton Agar (MHA) glass plates. 5 wells were dug in the sterile plates with a sterilized cork borer $(8 \mathrm{~mm})$ in diameter having same distance apart. The well were labeled according to the different concentrations of the soap prepared $(100 \mathrm{mg} / \mathrm{mL}$, $50 \mathrm{mg} / \mathrm{mL}, 25 \mathrm{mg} / \mathrm{mL}, 125 \mathrm{mg} / \mathrm{mL}$, and the control "CP" $\mathrm{mg} / \mathrm{mL}$ ). Sterilized filter paper was placed in the wells and the wells were made to have about $0.1 \mathrm{~m}$ of the different concentrations of the soap. The soap was allowed at room temperature for about one hour which is the pre-diffusion time before moved for incubation in an incubator for about $18-24$ hours.

After the incubation period, the plates were carefully observed as the extract was absorbed in the surrounding medium. The presence of microbial activity was observed to corrupt its organism and incubate the growth. The zone of inhibition was measured using a transparent ruler and the results were obtained and discussed.
Determination of Minimum Inhibitory Concentration (MIC)

The dilution was carried out by using tubes which were labeled and using the muller Hinton broth as the diluents, the lowest concentration of the soap showing inhibition for the organisms used were tested. The samples were well diluted in the tubes containing the Muller Hinton broth. The filter paper was removed for the samples and placed in the labeled bottle. They were incubated for $18-24$ hours The incubated samples were observed for the presence and absence of growth as the presence of growth showed a turbid reaction as the lowest concentration which showed no growth in the reaction was considered to be the minimum inhibitory concentration.

\section{Determination of Minimum Bactericidal Concentration (MBC)}

The results obtained from the minimum inhibitory concentration were used to conduct the minimum bactericidal concentration. A sterile wire loop was dipped into the test tubes. The plates were incubated at $37^{\circ} \mathrm{C}$ for $18-24$ hours. After the incubation period, the plates were examined for the presence and absence of growth. This was carried out to determine the microbial activity of the soap whether it killed the bacterial or growth was inhibited. If growth of the bacterial is observed the concentration of the extract turns turbid.

\section{RESULTS}

Table 3: Foamability, insoluble matter, moisture content, $\mathrm{pH}$, hardness, total fatty matter and Percentage total alkali (\%) for the soap samples A - K

\begin{tabular}{|c|c|c|c|c|c|c|c|}
\hline $\begin{array}{l}\text { Samples } \\
\text { produced }\end{array}$ & $\begin{array}{l}\text { Soap }+ \\
\text { foam }(\mathrm{cm})\end{array}$ & $\begin{array}{l}\text { Insoluble } \\
\text { matter }(\mathrm{g})\end{array}$ & $\begin{array}{l}\text { Moisture } \\
\text { content }\end{array}$ & $\mathrm{pH}$ & $\begin{array}{l}\text { Hardness } \\
(\mathrm{cm})\end{array}$ & $\begin{array}{l}\text { Tfm } \\
(\%)\end{array}$ & $\begin{array}{l}\text { Percentage total } \\
\text { alkali }(\%)\end{array}$ \\
\hline A & 12.0 & 0.50 & 14.6 & 9.0 & 0.55 & 72 & 0.31 \\
\hline B & 13.6 & 0.12 & 13.0 & 8.9 & 0.87 & 62 & 0.18 \\
\hline C & 15.0 & 0.40 & 18.6 & 8.1 & 0.83 & 60 & 0.12 \\
\hline D & 15.6 & 0.15 & 18.2 & 8.9 & 0.83 & 62 & 0.31 \\
\hline$E$ & 15.5 & 1.07 & 15.6 & 8.0 & 0.67 & 64 & 0.18 \\
\hline$F$ & 14.2 & 0.51 & 15.4 & 8.8 & 0.68 & 66 & 0.30 \\
\hline G & 15.3 & 0.33 & 15.0 & 7.9 & 0.60 & 66 & 0.31 \\
\hline $\mathrm{H}$ & 15.5 & 0.17 & 16.0 & 8.5 & 0.56 & 68 & 0.37 \\
\hline I & 15.5 & 0.16 & 14.2 & 8.8 & 0.50 & 72 & 0.18 \\
\hline ] & 14.6 & 0.16 & 15.6 & 8.3 & 0.53 & 70 & 0.37 \\
\hline K & 12.7 & 0.40 & 15.4 & 8.0 & 0.55 & 70 & 0.30 \\
\hline
\end{tabular}

Table 4: Sensitivity test of the each of the organisms on various concentrations of the soap extract

\begin{tabular}{|c|c|c|c|c|}
\hline \multirow[t]{2}{*}{ Test organisms } & \multicolumn{4}{|c|}{ Zone of inhibition $(\mathrm{mm})$ at varying concentrations $(\mathrm{mg} / \mathrm{mL})$} \\
\hline & 100 & 50 & 25 & 12.5 \\
\hline E. coli & 14.00 & 11.00 & 0.00 & 0.00 \\
\hline S. aureus & 13.20 & 12.00 & 0.00 & 0.00 \\
\hline S. typhi & 14.00 & 13.00 & 11.00 & 0.00 \\
\hline Control & 35.00 & 32.00 & 30.00 & 30.00 \\
\hline
\end{tabular}

Table 5: Minimum inhibitory concentration of the soap samples against the test samples

Test organisms $\quad$ Zone of inhibition $(\mathrm{mm})$ at varying concentrations $(\mathrm{mg} / \mathrm{mL})$

\begin{tabular}{lccccccccccc} 
& 100 & 50 & 25 & 12.5 & 6.25 & 3.125 & 1.56 & 0.78 & 0.39 & 0.195 \\
E. coli & - & $(\mathrm{MIC})$ & + & + & + & + & + & + & + & + & + \\
S. aureus & - & - & $(\mathrm{MIC})$ & + & + & + & + & + & + & + \\
S. typhi & - & - & (MIC) & + & + & + & + & + & + & + \\
Control & - & - & - & - & $(\mathrm{MIC})$ & + & + & + & + \\
\hline
\end{tabular}

Keys: MIC = Minimum inhibitory concentration (growth inhibition), (+) $=$ Growth/ turbidity. 
Table 6: Minimum bactericidal concentration of the soap samples against the test samples

\begin{tabular}{|c|c|c|c|c|c|c|c|c|c|c|}
\hline \multirow{2}{*}{$\begin{array}{l}\text { Test } \\
\text { organisms }\end{array}$} & \multicolumn{10}{|c|}{ Zone of inhibition $(\mathrm{mm})$ at varying concentrations $(\mathrm{mg} / \mathrm{mL})$} \\
\hline & 100 & 50 & 25 & 12.5 & 6.25 & 3.125 & 1.56 & 0.78 & 0.39 & 0.195 \\
\hline E. coli & $(\mathrm{MBC})$ & + & + & + & + & + & + & + & + & + \\
\hline S. aureus & - & $(\mathrm{MBC})$ & + & + & + & + & + & + & + & + \\
\hline S. typhi & $(\mathrm{MBC})$ & + & + & + & + & + & + & + & + & + \\
\hline Control & - & - & $(\mathrm{MBC})$ & + & + & + & + & + & + & + \\
\hline
\end{tabular}

Keys: MBC - Minimum Bactericidal Concentration (Kills Bacterial), (+) = Growth/ turbidity.

\section{DISCUSSION}

From analysis, the percentage total alkali of the soaps produced was found to be in the range of $(0.18$ $0.37)$, thus the value is low and indicates that the soap formed will not be harsh on the skin (Taiwo, A. 2008).

The results of the TFM also indicates that the soap produced can be used as toilet soap; (\%TFM for toilet soap is $60 \%$ and above) (ADAC, 1998). The differences in the TFM are responsible for high moisture contents and quantities of the used fatty materials. However, dry skin needs soap which is high in a total fatty matter to re-hydrates the skin making it smooth, and also serves as a lubricant (Ara, I. 2010).

The hardness test revealed the extent of penetration of the loaded needle on the soap samples. Soap B, derived from $100 \%$ soya oil recorded the highest, $0.87 \mathrm{~cm}$ as compared to the control sample, $0.45 \mathrm{~cm}$. Furthermore, it was also observed that the higher the quantity of soya bean oil in the blends, the softer the soaps produced and also, the higher the penetration of the loaded needle.

$\mathrm{pH}$ of the soaps produced from the oil blends $\mathrm{A}, \mathrm{B}, \mathrm{C}$, $D, E, F, G, H, I, J$ and $K$ falls within standard recommended $\mathrm{pH}$ for bathing soap as indicated by Mak-Mensah (2011). The results also conform to recommended $\mathrm{pH}$ for National Agency for Food and Drug Administration and Control (NAFDAC) (Umar, 2002). Hence, the soaps produced, are not harmful to the skin.

From the results obtained in Table 3, soaps produced from the blends have shown maximum moisture content value of 18.6 which is slightly higher than the ASTMD455-69 (2006) specification of 15\% maximum. This could be due to the minimum curing period of the soap and the reaction of an incomplete base in the soap. The matter insoluble in water was also determined which is the ability of soap to dissolve completely during use without leaving traces on the substrates. From the results obtained, the soaps produced fall within the American specification of $1.00 \%$. Furthermore, the foaming ability of the soaps produced from the blends were observed to have higher foams of $(12.7-15.6 \mathrm{~cm})$ as compared to the control sample that recorded $12.0 \mathrm{~cm}$. The result also conformed to (Taiwo et al, 2008).

\section{Sensitivity test}

Table 4 shows the result for microbial activity of the soap. The control sample has the highest concentration for the zone of inhibition at $100 \mathrm{mg} / \mathrm{mL}$ for the Escherichia coli which proves that the control sample have a higher microbial activity than the produced blend of soap. Hence, the produced soap also shows microbial activity which makes it good for commercial use.

From the results, the staphylococcus aureus bacterial used on the soap extract shows a higher zone of inhibition of the control sample compared to the produced soap samples. Hence the control sample has a higher sensitivity to the tested organisms compared to the produced blend of soap. In comparing the third bacterial, salmonella typhi at concentration of $100 \mathrm{mg} / \mathrm{mL}$, the control sample also was seen to have a higher microbial sensitivity than the produced neem soap. From the results, the produced neem soap also showed favourable sensitivity to the bacteria as compared to the control sample. Hence, the produced neem soap could be compared to the control sample in terms of the salmonella typhi bacterial.

The results obtained from Table 5; Minimum inhibitory concentration of the soap samples and Table 6; Minimum bactericidal concentration of the soap samples against the three bacterial when tested were determined. From the results of the minimum inhibitory concentration tested on the Escherichia coli bacterial, the produced blend of soap was able to inhibit growth at a concentration of $50 \mathrm{mg} / \mathrm{mL}$ and in the minimum bactericidal concentration, the results shows the bacterial is killed at $100 \mathrm{mg} / \mathrm{mL}$. Hence the soap can inhibit and kill organisms present.

In analysis of the staphylococcus aureus, from results obtained, the produced neem soap was able to inhibit the bacterial at a lower concentration of $25 \mathrm{mg} / \mathrm{mL}$ and kill the bacterial completely at a concentration of $50 \mathrm{mg} / \mathrm{mL}$ in the MIC and MBC test respectively. The third bacteria, salmonella typhi on the produced samples showed that at a concentration of $25 \mathrm{mg} / \mathrm{mL}$, the sample was able to inhibit the presence of bacterial in the MIC test and at a concentration of $100 \mathrm{mg} / \mathrm{mL}$, the bacteria was completely killed in the sample.

\section{CONCLUSION}

Preparation of soap was carried out using various blends of neem and soya bean oils. The soap was tested for various properties and compared with commercial soap. Single soap making oil in itself does not have all the properties. Therefore, blends of oils were prepared taking 2 oils together because it gives better properties in analysis. 
All necessary properties like $\mathrm{pH}$, Hardness, Total Fatty Matter, Moisture Yield, and Microbial activity of the soap were all studied to select the best blend out of all the blends thus, indicating sample I; $70 \%$ neem / $30 \%$ soya bean, and sample D $80 \%$ soya bean / $20 \%$ neem to be highly preferred for soap making. Comparing the results of the test for the soap produced with the commercial soap used as the control sample, the minimum inhibitory concentration of the control sample at a concentration of $6.25 \mathrm{mg} / \mathrm{mL}$ was able to inhibit the growth of the bacterial, and in the determination of the minimum bactericidal concentration, the bacterial completely killed at a concentration of $25 \mathrm{mg} / \mathrm{mL}$.

Based on the results obtained and analysis it's clearly indicated that both neem oil and soya oil can be utilized for commercial soap production.

\section{REFERENCES}

Ara, I., Siddiqui, B.S. and Faizi, S. (2 010). Tricyclic diterpenes from the stem bark of Azadirachta indica. Photochemistry. 53: 816-820.

Jackson, C.J.C, Dini, J. P, Lavandier, C, Rupasinghe, H.P.U., Faulkner, H., Poysa, V., Buzell, D. and Dehrandic, S. (2002). Effects of Processing on the Content and Composition of Isoflavones during Manufacturing of Soya Beverage. Process Biochemistry 37, 11171123

Kuntom, A., Kifli, H. and Lim, P.K. (1996): Chemical and Physical Characteristics of Soap Made from Distilled Fatty acids of Palm oil and Palm-kernel oil. J. Am. OilChern Soc. 73, 105-108.

\section{Recommendations}

Neem oil is seen as very good oil which possesses a high quality in production. The production of soap with neem oil should be encouraged and more research on the oil

The availability of the neem oil from seed extraction should be made abundant and refined for large scale productions. Thus, other blends of vegetable oil can be incorporated to give a better quality of soap. The action of bacteria on the soap were analyzed using three isolated bacteria (Escherichia coli, Staphylococcus aureus and Salmonella typhi), other bacteria can be used and related experiments can be done to analyze the effect of different kinds of soap produced.

\section{Author's Contribution}

This work was carried out in collaboration between all authors. All authors read and approved the final manuscript.

Olatuja, G. (2013). Proposal on Soap Research Project. Self-strong Group of Companies. Chapter $1-4$.

Taiwo, A. A., Oluwadare, I., Shobo, A. O. and Amolegbe, S. A. (2008). Extraction and potential application of caustic potash from kolanut husk, ugwu pod husk and plantain peels. Scientific Research and Essay. 3: 515517.

Umar, M (2002). Cosmetics, Soaps, Detergents and NAFDAC's Regulatory Requirements. A paper presented at a Training workshop for Small and Medium Scale Enterprises. 